University of South Florida

DIGITAL COMMONS

@ UNIVERSITY OF SOUTH FLORIDA
Digital Commons @ University of

South Florida

$7-1-2004$

\title{
Florida Statewide TDM Clearinghouse
}

CUTR

Follow this and additional works at: https://digitalcommons.usf.edu/cutr_nctr

\section{Recommended Citation}

"Florida Statewide TDM Clearinghouse," National Center for Transit Research (NCTR) Report No. CUTRNCTR-RR-2016-03, Center for Urban Transportation Research, University of South Florida, 2004.

DOI: https://doi.org/10.5038/CUTR-NCTR-RR-2016-03

Available at: https://scholarcommons.usf.edu/cutr_nctr/90

This Technical Report is brought to you for free and open access by the National Center for Transit Research (NCTR) Archive (2000-2020) at Digital Commons @ University of South Florida. It has been accepted for inclusion in Research Reports by an authorized administrator of Digital Commons @ University of South Florida. For more information, please contact digitalcommons@usf.edu. 


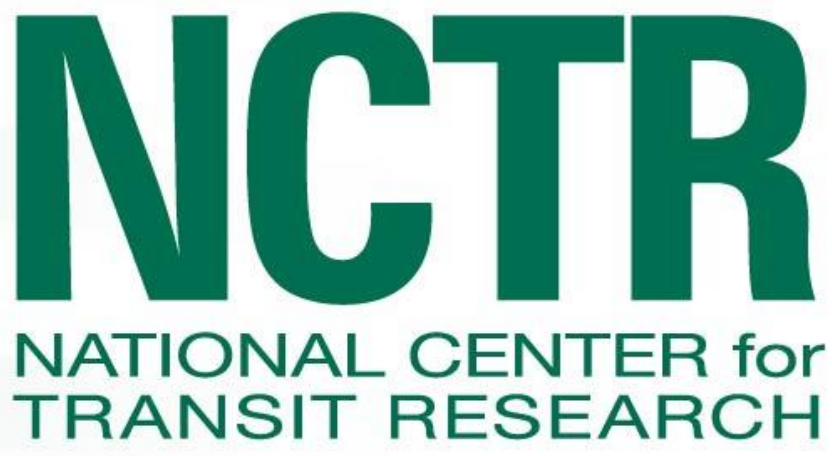

\section{Florida TDM Clearinghouse Final Report}

January 2017

FDOT PROJECT NO. BDV25-TWO 943-11

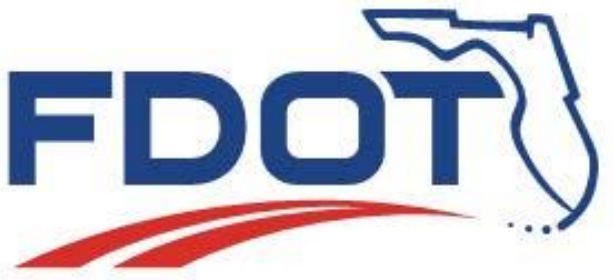




\section{Disclaimer}

The contents of this report reflect the views of the authors, who are responsible for the facts and the accuracy of the information presented herein. This document is disseminated under the sponsorship of the Department of Transportation University Transportation Centers Program and the Florida Department of Transportation, in the interest of information exchange. The U.S. Government and the Florida Department of Transportation assume no liability for the contents or use thereof.

The opinions, findings, and conclusions expressed in this publication are those of the authors and not necessarily those of the State of Florida Department of Transportation. 


\section{Metric Conversion}

\begin{tabular}{|c|c|c|c|c|}
\hline SYMBOL & WHEN YOU KNOW & MULTIPLY BY & TO FIND & SYMBOL \\
\hline \multicolumn{5}{|c|}{ LENGTH } \\
\hline in & inches & 25.4 & millimeters & $\mathrm{mm}$ \\
\hline $\mathrm{ft}$. & feet & 0.305 & meters & $\mathrm{m}$ \\
\hline yd. & yards & 0.914 & meters & $\mathrm{m}$ \\
\hline $\mathrm{mi}$ & miles & 1.61 & kilometers & $\mathrm{km}$ \\
\hline \multicolumn{5}{|c|}{ VOLUME } \\
\hline fl. oz. & fluid ounces & 29.57 & milliliters & $\mathrm{mL}$ \\
\hline gal & gallons & 3.785 & liters & L \\
\hline $\mathrm{ft}^{3}$ & cubic feet & 0.028 & cubic meters & $\mathrm{m}^{3}$ \\
\hline$y d^{3}$ & cubic yards & 0.765 & cubic meters & $\mathrm{m}^{3}$ \\
\hline \multicolumn{5}{|c|}{ NOTE: volumes greater than $1000 \mathrm{~L}$ shall be shown in $\mathrm{m}^{3}$} \\
\hline \multicolumn{5}{|c|}{ MASS } \\
\hline oz. & ounces & 28.35 & grams & $g$ \\
\hline lb. & pounds & 0.454 & kilograms & $\mathrm{kg}$ \\
\hline $\mathbf{T}$ & Short tons (2000 lb.) & 0.907 & $\begin{array}{l}\text { megagrams } \\
\text { (or "metric ton") }\end{array}$ & Mg (or "t") \\
\hline \multicolumn{5}{|c|}{ TEMPERATURE (exact degrees) } \\
\hline${ }^{\circ} \mathrm{F}$ & Fahrenheit & $\begin{array}{c}5(\mathrm{~F}-32) / 9 \\
\text { or }(\mathrm{F}-32) / 1.8\end{array}$ & Celsius & ${ }^{\circ} \mathrm{C}$ \\
\hline
\end{tabular}




\section{Technical Report Documentation}

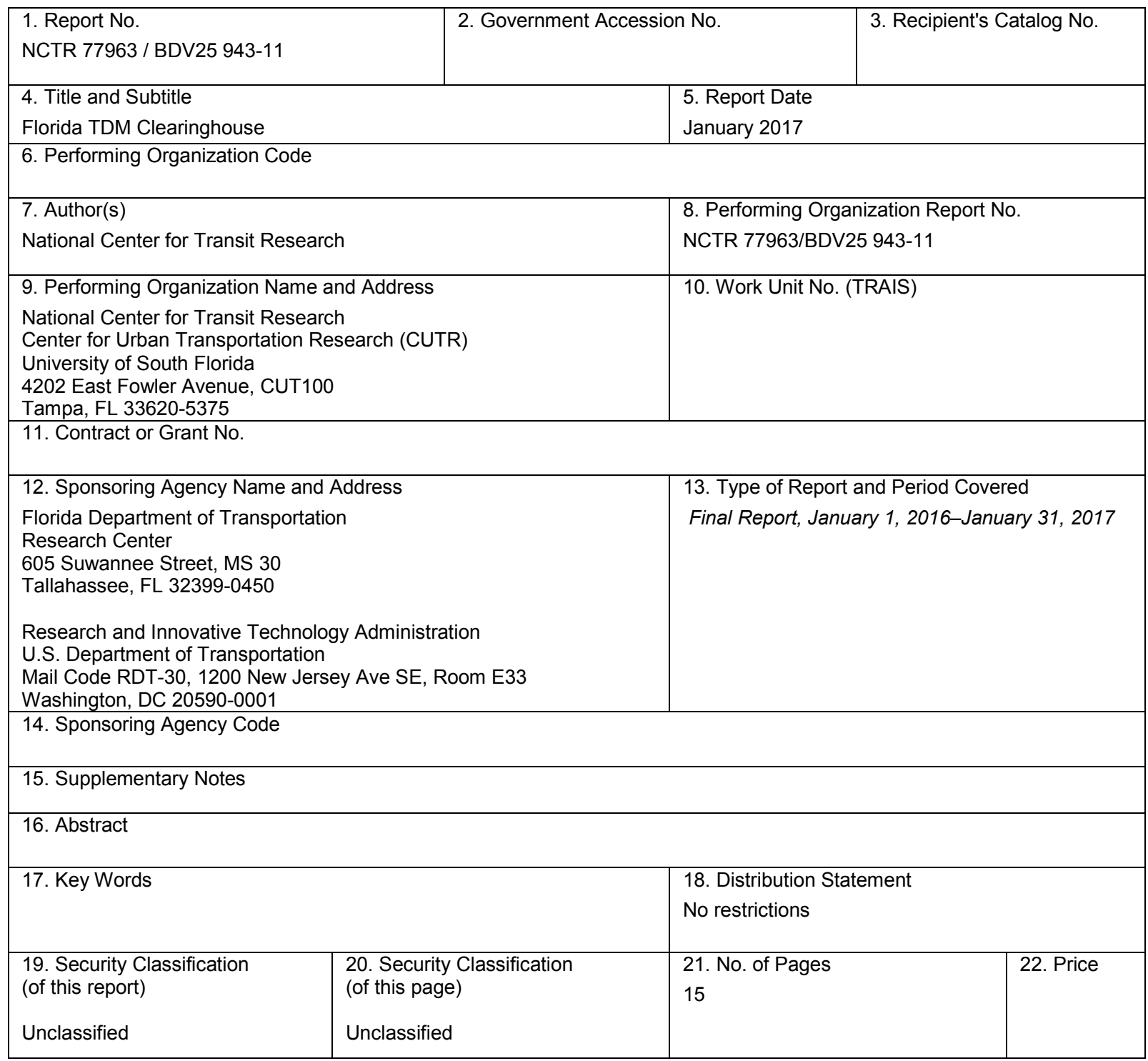




\title{
FINAL REPORT
}

\author{
Florida TDM Clearinghouse \\ For the Period of January 1, 2016 through January 31, 2017 \\ FOOT Contract \#BDV25 TWO 943-11 \\ USF Account 21177981-00
}

The following final report summarizes the significant activities of the Florida TOM Clearinghouse in 2016. Additional detail is available in the previously submitted quarterly reports.

\section{Task 1: Technical Assistance Support}

Under this task, CUTR provides technical assistance using a range of methods from fostering self-service to short-term on-site support as described below.

Listservs. NCTR hosts six listservs in direct support of commuter assistance programs and/or Florida employers. Their purpose is to allow commuter assistance programs, state departments of transportation, transportation management associations (TMAs), and the Clearinghouse to email their peers across the world to help answer questions and solve problems. The TRANSP-TDM listserv membership is the largest, with 2,582 active members with a net increase of 303 members in 2016 . The number of messages successfully delivered by the TRANSPTDM listserv ranged from 231,000 to 298,000 per quarter.

Given we were reaching the maximum subscriber limit $(10,000)$ across all our listservs, we will be transitioning from CUTR hosted Lyris ListManager to USF hosted L-Soft. Lyris was acquired by another company (Aurea). Aurea is packaging the listserv with other products and pricing on a per-subscriber basis. We determine this was untenable. We are working with USF IT to begin moving the email lists and archives over to L-Soft which will begin in 2017 .

\begin{tabular}{|c|c|c|c|c|c|c|c|}
\hline Listserv & $\begin{array}{l}\text { Net Total } \\
\text { Members }\end{array}$ & & Chan & e by $F$ & iod & & $\begin{array}{l}\text { Date } \\
\text { Listserv } \\
\text { Established }\end{array}$ \\
\hline & & Q1 & Q2 & Q3 & Q4 & Year & \\
\hline Transportation Demand Management & 2582 & 103 & 75 & 77 & 48 & 303 & Oct-98 \\
\hline Parking Management & 453 & 12 & 16 & 7 & 10 & 45 & Feb-07 \\
\hline Telework & 433 & 7 & -2 & 7 & 3 & 15 & Dec-99 \\
\hline Best Workplaces for Commuters & 208 & 7 & 10 & 6 & 7 & 30 & Jul-07 \\
\hline $\begin{array}{l}\text { Best Workplaces for Commuters } \\
\text { Champions }\end{array}$ & 144 & 4 & 1 & 3 & 6 & 14 & Jul-09 \\
\hline Large Employers Council & 32 & 4 & 3 & 5 & 5 & 17 & Aug-15 \\
\hline
\end{tabular}


Online TOM knowledge base. The Clearinghouse's online TDM knowledge base (KB) provides an intelligent selfservice option by providing information on hundreds of frequently asked questions as well as case studies and examples. This approach provides a means to reduce the total number of basic inquiries or repeat requests that require personal attention. It also allows staff to quickly respond to inquiries drawing on the information in the KB. The objective is to be more cost-effective as the Clearinghouse seeks to handle more interactions by providing lower cost transactions with the KB's self-service feature. In 2016, the KB had 1,203 searches and 77,288 answers viewed.

\begin{tabular}{|c|c|c|}
\hline Quarter & $\begin{array}{c}\text { Number of } \\
\text { Searches }\end{array}$ & Answers Viewed \\
\hline Q1 & 523 & 24,434 \\
Q2 & 125 & 18,172 \\
Q3 & 274 & 17,576 \\
Q4 & 281 & 17,106 \\
Total & 1,203 & 77,288 \\
\hline
\end{tabular}

On-demand short-term technical support and limited on-site technical assistance. Activities include, but are not limited to, requests from Florida CAP programs, FDOT Districts, and TRANSP-TDM listserv postings. Postings to the listserv also include an autoresponder message pointing them to the online knowledge base and other resources. Refer to the quarterly reports for details.

\begin{tabular}{|c|c|c|c|c|}
\hline Quarter & $\begin{array}{l}\text { Questions/ } \\
\text { Replies Posted } \\
\text { to TRANSP- } \\
\text { TDM Listserv }\end{array}$ & RFPs & $\begin{array}{c}\text { Event } \\
\text { Announcements } \\
\text { (e.g., } \\
\text { conferences, } \\
\text { webinars) }\end{array}$ & Job Openings \\
\hline Q1 & 62 & 8 & 15 & 26 \\
\hline Q2 & 134 & 10 & 23 & 32 \\
\hline Q3 & 134 & 3 & 18 & 29 \\
\hline Q4 & 135 & 12 & 9 & 27 \\
\hline Total & 465 & 33 & 65 & 114 \\
\hline
\end{tabular}




\section{Task 2: Outreach and Communications}

\section{Netconferences}

We sponsored or co-sponsored the following five netconferences/webinars in 2016:

- On January 19, 2016, Best Workplaces for Commuters (BWC) and the Association for Commuter Transportation (ACT) co-sponsored, Learn about US DOT's $\mathbf{4 0}$ million Smart Cities Challenge netconference, to introduce attendees to US DOT's $\$ 40$ million Smart Cities Challenge. This competition presents a tremendous opportunity for TOM and transit professionals to get engaged. During the presentation, ACT Government Affairs Director Jason Pavluchuk provided valuable information on the program including: background on the program, who is eligible to participate, timing of the program, and how ACT Members, both public and private, can get involved. See more at: http://www.bestworkplaces.org/webconferences/webinar-learn-about-us-dots-40-million-smart-cities-challenge/

- On January 28, 2016, Best Workplaces for Commuters and the Association for Commuter Transportation cosponsored this webinar to summarize the provisions of the Fixing America's Surface Transportation Act, or "FAST Act" law. The presentation highlighted the first Federal law in over ten years to provide long-term funding certainty for surface transportation. Jason Pavluchuk, ACT's government relations representative, discussed changes that create opportunities for the potential expanded role for employers to have a stronger voice in the transportation planning process. Mr. Pavluchuk summarized the Congestion Mitigation Air Quality (CMAQ) Program as a Federal Highway formula program for which a wide variety of TOM and employer-based commuter activities are eligible for funding. He also addressed the new Surface Transportation Block Grant program which replaces the Surface Transportation Program. Finally, he noted that a new program, Advanced Transportation \& Congestion Management Technologies Deployment, may have the largest, long-term effect on TOM. Under this innovation program, USDOT will annually award grants to model deployment sites for large scale installation \& operation of advanced technologies to address transportation problems. Future webinars will discuss these policies and programs in more detail. See more at: http://www.bestworkplaces.org/events/fast-act-recap-webinar-recording

- On May 11, 2016, Best Workplaces for Commuters (BWC) and Association for Commuter Transportation (ACT) hosted the webinar, "TDM Technologies for Employers: How Does Yours Stack Up?" Wendy Scholtz, ACT's Employer Council Chairperson and Transportation Demand Management Specialist with the CBRE /Microsoft Commute, along with Julie Bond, Project Manager for BWC co-moderated the event. This 75minute webinar featured three stellar employee commute programs, Nick Amatuzzi of The MITRE Corporation, Bree Moore of the Bill and Melinda Gates Foundation, and Amy Lawson of Genentech. They provided an overview of their employee commute programs and the technologies used to implement them. Access the recording at http://www.bestworkplaces.org/web-conferences/bwcact-employer-councilwebinar/

- On May 26, 2016, we cohosted "Proposed Federal Transportation Performance Measures: Opportunities and Challenges for TDM Communities" with ACT's Public Policy Council. Jason Pavluchuk, founder of Pavluchuk \& Associates, discussed the proposed federal transportation performance measures and why it's important for all TOM professionals to become familiar with this process and understand the impact it will

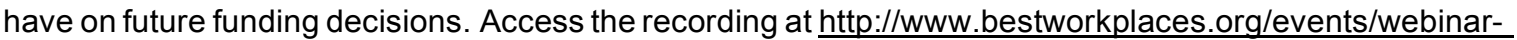
fed-performance-measures/

- On August 31, 2016 and September 7, 2016, we conducted a 2-part webinar webinar series, "Engaging Employers and Developers in TDM through LEED, Best SITES and other Recognition Programs" These webinars discussed how programs such as LEED, Best Workplaces for Commuters' Best SITES, and AASHE 
STARS for universities can help motivate employers and developers to adopt and enhance transportation demand management offerings. Recordings are available at http://www.bestworkplaces.org/webconferences/webinar-engaging-employers-and-developers-in-tdm-through-leed-best-sites-and-otherrecognition-progra $\mathrm{ms} /$

Planning also was under way for several 2017 webinars.

Website (www.commuterservices.com)

Clearinghouse staff use Google Analytics reports to track activity, usage, etc. on the Florida TDM Clearinghouse website (www.commuterservices.com) and Best Workplaces for Commuters (www.bestworkplaces.com) . Below summarizes the number of users and number of page views for each website per quarter.

\begin{tabular}{|c|c|c|}
\hline Quatiser & $\begin{array}{l}\text { Conmuterser } \\
\text { Jimber of } \\
\text { Users }\end{array}$ & 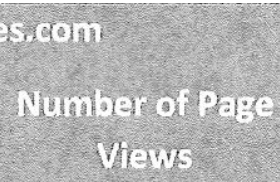 \\
\hline Q1 & 1,022 & 3,320 \\
\hline Q2 & 1,306 & 2,473 \\
\hline Q3 & 1,305 & 2,459 \\
\hline Q4 & 575 & 1,354 \\
\hline Total & 4,208 & 9,606 \\
\hline
\end{tabular}

\begin{tabular}{|c|c|c|}
\hline Quarter & $\begin{array}{c}\text { Besimpoliplaressom } \\
\text { Number of } \\
\text { Users }\end{array}$ & $\begin{array}{c}\text { Number of Page } \\
\text { Vhews }\end{array}$ \\
\hline Q1 & 3,189 & 2,396 \\
\hline Q2 & 3,061 & 6,737 \\
\hline Q3 & 3,167 & 11,461 \\
Q4 & 4,283 & 17,656 \\
Total & 13,700 & 38,250 \\
\hline
\end{tabular}




\section{Best Workplaces forCommuters}

To foster employer participation in commuter services programs, the Clearinghouse partially supports the identification and recognition of employers that meet the Best Workplaces for Commuters' National Standard of Excellence. At the end of the year, we had identified 57 workplaces in Florida (see membership below\}. The promotion of the program varies by district. Most Non-Florida workplaces pay $\$ 190$ to $\$ 230$ per year membership fee to help support the program.

\section{Annual BWC List Release}

On January 31, 2017 we announced the BWC 2017 Annual List with 232 on the national list. With the assistance of Day Communications (paid entirely from the membership fees of BWC members\}, we issued a press release to that was distributed on a national newswire. This step included the building of a targeted list of transportation and TDM industry/trade publications (such as Mobility Lab and Streetsblog\} to receive the press release. Day sent personalized emails with the press release to each industry publication contact on the list. They also created a BWC media kit for employers including a press release template, logo, fact sheet and approved talking points for media, under CUTR's guidance For the employers, they created a BWC social media kit for employers to use on their social media platforms (Facebook, Twitter, Linkedln, Instagram and Blog). Kit included messaging examples; photos/images; relevant hashtags, usernames and handles; and links for BWC employers to use on social media platforms. Day is gathering information for a summary of media and social media report showing clips, metrics and reach of the wire distribution, any stories placed from targeted industry/trade outreach, and social media posts by employers.

\section{BWC Membership List - Florida members only}

1. Acomb Ostendorf \& Associates (Winter Park, FL)

2. Bank of America (Tampa, FL\}

3. Bealls, Inc. (Bradenton, $\mathrm{FL}$ \}

4. CareerSource Brevard (Rockledge, FL\}

5. Center for Urban Transportation Research (Tampa, FL\}

6. Central Florida Regional Planning Council (Bartow, FL\}

7. Charlotte County Board of County Commissioners (Port Charlotte, FL\}

8. City ofCasselberry (Casselberry, $\mathrm{FL}$ \}

9. City of Orlando (Orlando, $\mathrm{FL}\}$

10. City of Naples (Naples, FL\}

11. City of North Port (North Port, FL\}

12. City of Sarasota (Sarasota, FL\}

13. Collier County Government (Naples, FL\}

14. Department of Homeland Security, U.S. Citizenship and Immigration (Orlando, FL\}

15. Dix.Hite+ Partners, Inc. (Longwood, FL\}

16. Environmental Protection Commission of Hillsborough County (Tampa, FL\}

17. Everest University (Lakeland, FL\}

18. FBC Mortgage, LLC \{Orlando, FL\}

19. Florida Department of Environmental Protection - Central District \{Orlando, FL\}

20. Florida Department of Environmental Protection \{Fort Myers, FL)

21. Florida Hospital Orlando \{Orlando, FL\}

22. Greater Orlando Aviation Authority \{Orlando, FL\}

23. HDR, Inc. (Orlando, FL\}

24. Hillsborough Area Regional Transit Authority (Tampa, FL\}

25. IBM $\{$ Boca Raton, FL $\}$ 
26. Lee County Board of County Commissioners \{Fort Myers, FL)

27. Lee County Clerk of Courts \{Fort Myers, FL)

28. Lee County DOT/Operations \{Fort Myers, FL)

29. LEGOLAND Florida \{Winter Haven, FL)

30. LYNX - Central Florida Regional Transportation Authority \{Orlando, FL)

31. MetroPlan Orlando \{Orlando, FL)

32. Net Conversion \{Orlando, FL)

33. Orange County Library System \{Orlando, FL)

34. Orlando Senior Health Network \{Orlando, FL)

35. Orlando VA Medical Center (Orlando, FL)

36. Orlando VA Medical Center -Viera Outpatient Clinic \{Viera, FL)

37. Pinnacle Property Management Services \{Maitland, FL)

38. PlanSource \{Orlando, FL)

39. Polk State College (Winter Haven and Lakeland, FL)

40. PowerDMS \{Orlando, FL)

41. PRPL.RS \{Orlando, $\mathrm{FL}$ )

42. Ravago Americas (Orlando, FL)

43. Sarasota County Government \{Sarasota, FL)

44. smart panda labs \{Orlando, $\mathrm{FL}$ )

45. South Florida Commuter Services \{Fort Lauderdale, FL)

46. South Seas Island Resort \{Captiva, FL)

47. Space Coast Area Transit (Cocoa, FL)

48. TBARTA \{Tampa, FL)

49. Tampa Downtown Partnership, (Tampa, FL)

50. Tindale-Oliver \& Associates, Inc. \{Orlando, FL)

51. Tindale-Oliver \& Associates, Inc. (Tampa, FL)

52. Town Center at Boca Raton (Boca Raton, FL) *Best SITE

53. University of Florida \{Gainesville, FL)

54. University of Miami \{Coral Gables, FL)

55. University of South Florida (Tampa, FL)

56. VHB \{Orlando, FL)

57. William V. Chappell, Jr. VA Satellite Outpatient Clinic \{Daytona Beach, FL)

\section{Race to Excellence}

TAMPA, Fla. (December 15, 2016) - Best Workplaces for Commuters, a program designed to encourage sustainable transportation innovation singled out 17 employers nationwide Thursday, December $15^{\text {th }}$ during the annual "Race to Excellence" Virtual Awards Ceremony. The awards recognize organizations who have taken exemplary steps to offer transportation options such as vanpool and transit benefits or telework and compressed workweek for their employees. "The annual Race to Excellence provides national recognition for employers who offer high level commuter benefits," said Julie Bond, CUTR's national program manager for Best Workplaces for Commuters. "Offering commuter benefits is a win-win situation for employees who change their commuting habits to save time, money, and stress and employers who gain a competitive edge in employee recruitment and retention. This year we recognized 18 Race to Excellence winners who have exceptional commute programs." Best Workplaces for Commuters provides qualified employers with programs and services along with national recognition and an elite designation for offering outstanding commuter benefits, such as free or low cost bus passes. Employers that meet the National Standard of 
Excellence in commuter benefits, a standard established by the U.S. Environmental Protection Agency (EPA) and maintained by the Center for Urban Transportation Research (CUTR), can become a member of Best Workplaces for Commuters.

\author{
"Best Of" the Race to Excellence \\ Support Agency- San Luis Obispo Council of Governments (SLOCOG), San Luis Obispo, CA \\ University - University of North Carolina at Greensboro, Greensboro, NC \\ Employer - Mayo Clinic, Rochester, MN \\ Best SITE - Hacienda, Pleasanton, CA
}

\title{
Race to Excellence Winners:
}

\section{Support Agency}

Commuter Services of Pennsylvania, York, PA

GVF, King of Prussia, PA

San Luis Obispo Council of Governments (SLOCOG), San Luis Obispo, CA

Suburban Transit Network, Inc. (TransNet), Blue Bell, PA

Triangle J Council of Governments, Durham, NC

\section{University}

University of North Carolina at Greensboro, Greensboro, NC

\section{Employer}

Booz Allen Hamilton, McLean, VA

City of Raleigh, Raleigh, NC

GoRaleigh, Raleigh, NC

GVF, King of Prussia, PA

Mayo Clinic, Rochester, MN

North Carolina Department of Environmental Quality, Raleigh, NC

The MITRE Corporation, McLean, VA

Tindale Oliver, Tampa, FL

Yale New Haven Hos_pital, New Haven, CT 


\section{Best SITE}

Access Tysons, McLean,

VA Hacienda, Pleasanton, CA

$\underline{\text { View Virtual Ceremony Slides }}$

View Recording of Virtual Ceremony

See more at: https://www.bestworkplaces.org/race-to-excellence-2/2016-race-to-excellence-results/

The 2016 Best Workplaces for Commuters Race to Excellence Kickoff webinar was held on March 10, 2016. The webinar allowed potential participants in the race to learn the rules and procedures to participate in the Race this year. Organizations will be able tInnovative Program: Commuter Services, District 1 "Innovative Concepts on a Shoestring Budget" o enter achievements during the year on the BWC website and track progress toward bronze, silver or gold as well as their rank among race participants. The webcast spotlighted the winner of 2015 "Best of" Supporting Agency: reThink of Orlando, Florida. reThink shared highlights of their gold-level efforts and how the reThink support program is growing and innovating. See more at: http://www.bestworkplaces.org/race-to-excellence- 2/2016-ra ce-toexcellence-kickoff/

\section{Florida Commuter Transportation Summit}

The 2016 Florida Commuter Transportation Summit, sponsored by the Florida Department of Transportation, and hosted by the Center for Urban Transportation Research was held in Tampa, Florida on April 14 and 15, 2016. The program can be viewed at http://www.commuterservices.com/wp-content/uploads/2016/03/Summit-2016-Programsmall.pdf and the proceedings can be found at http://www.commuterservices.com/2016-florida-commutertransportation-summit-proceedings/

The Summit was proceeded by a half-day training class "Social Media Marketing: Opportunities \& Pitfalls for Public Transportation Professionals" taught by Dr. Luke Hopkins, Professor of Marketing at Florida State University. Participants will receive 4 credits under the Commuter Choice Certificate program. The Keynote Speaker was Michelle Olson with Lyft. Michelle is a Transportation Solutions Manager for Lyft, a ride-sharing company headquartered in San Francisco, CA.

At the Summit, FDOT announced the following winners of its Florida Travel Choices Awards. 


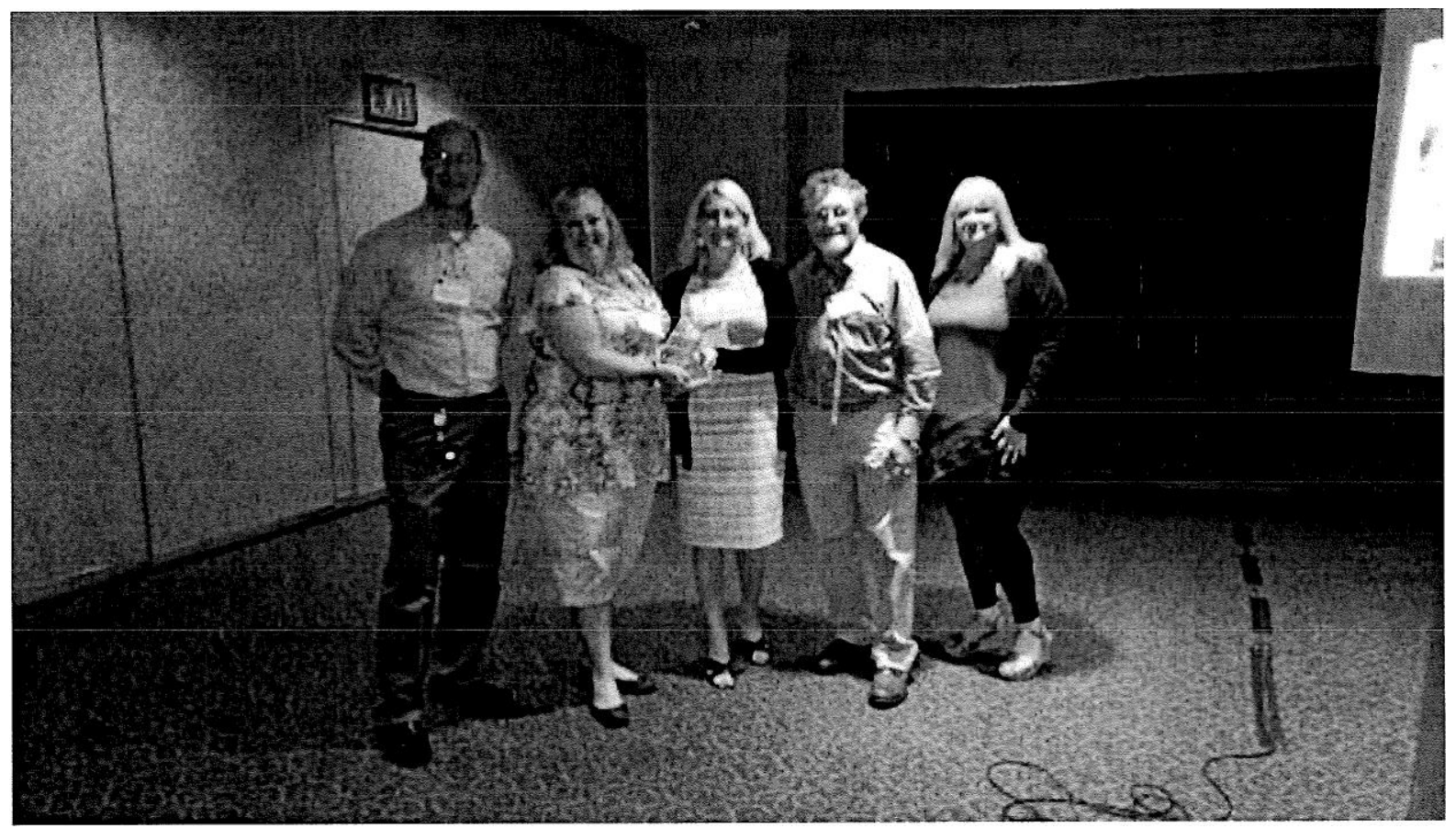

Innovative Program: Commuter Services, District 1: "Innovative Concepts on a Shoestring Budget"

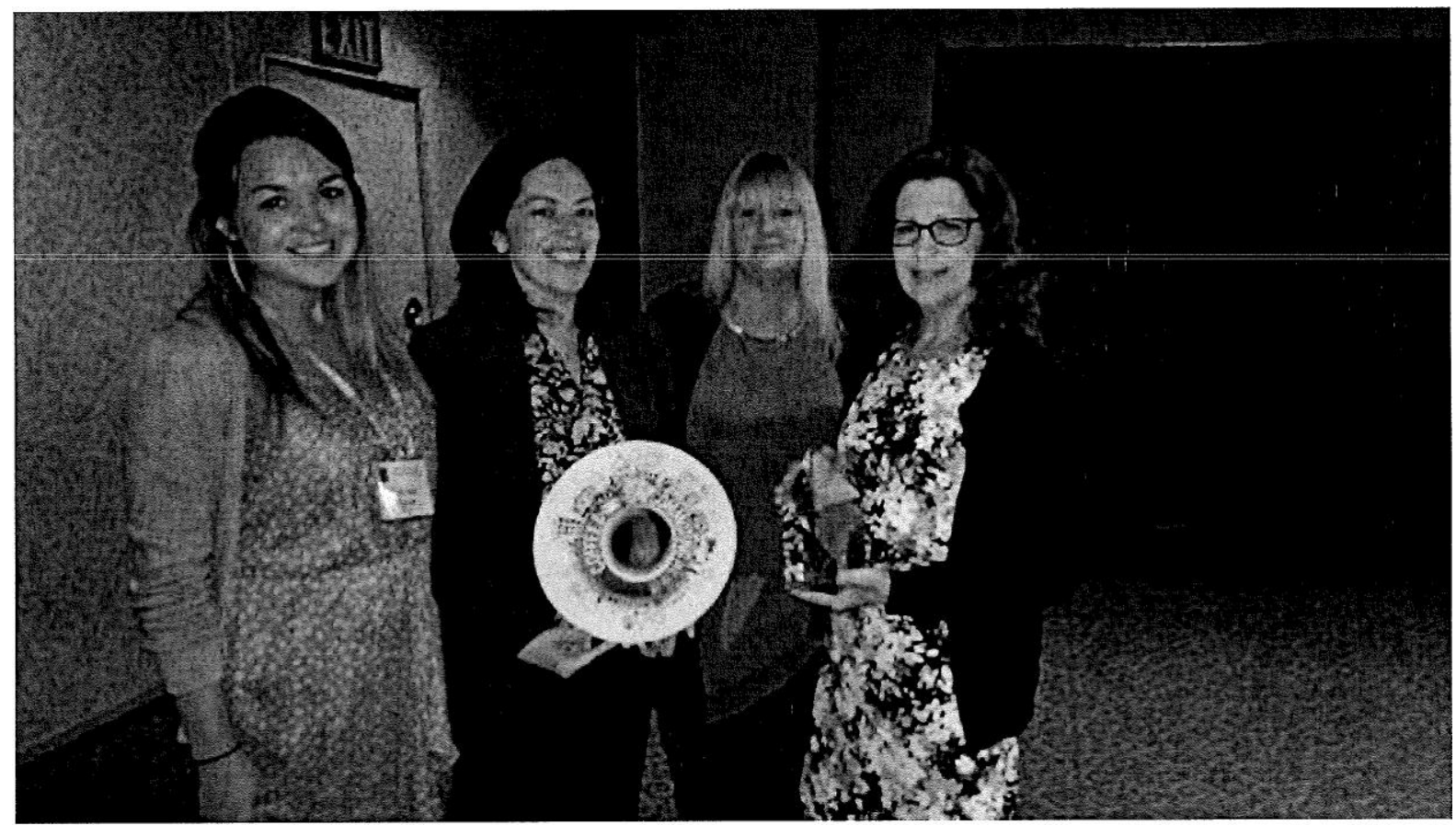

Marketing Excellence: reThink, "Coffee \& Commuting" 


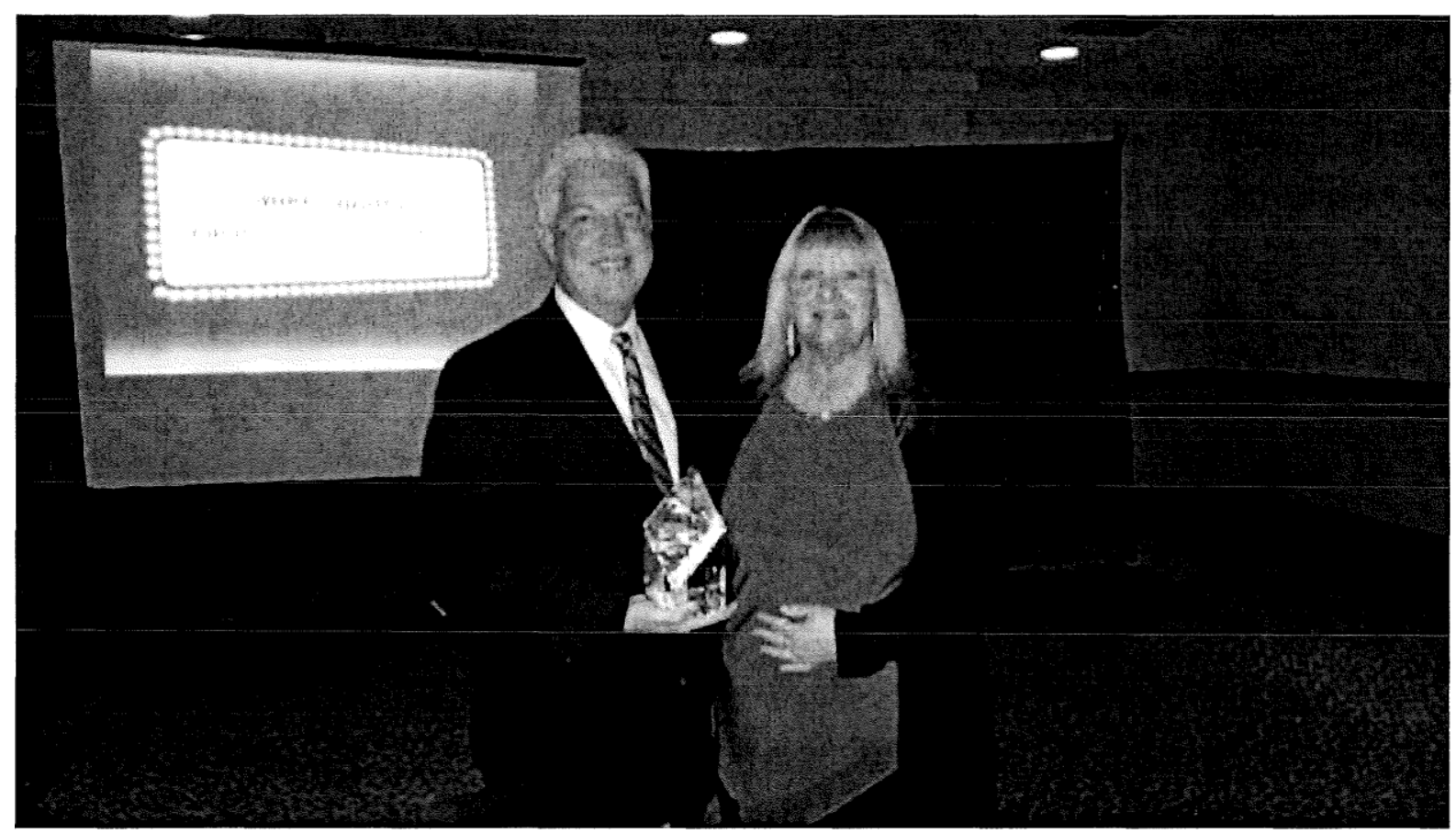

Leadership: Mike Suarez, Tampa City Councilman

The 2017 Florida Commuter Transportation Summit, sponsored by the Florida Department of Transportation, and hosted by the Center for Urban Transportation Research will be held in St. Petersburg, Florida. Planning has begun for the Summit. Negotiations for hotel were handled and it will be at Hotel Indigo in St. Petersburg. CUTR will conduct a "Assessing Walkability for Workplaces" training session as part of the Summit.

\section{Professional Development and Organizational Learning}

Clearinghouse staff participated in conference calls with the Association for Commuter Transportation on issues of public policy, sustainability, vanpooling and telework. Proposals for presentations were submitted to ACT, including three professional development workshops on Sunday before the ACT conference.

Proposals for staff to conduct five presentations were accepted to ACT along with two professional development workshops:

1. Professional Development Workshop \#1: Advancing TDM through LEED and Other Recognition Programs (Sara Hendricks)

2. Professional Development Workshop \#4: Developing Creative Thinking Skills for TDM Professionals (Phil Winters)

3. Increasing our Impact: Forming Coalitions and Partnerships to Improve Transportation Options (Julie Bond)

4. Closing the Gap: The First, Last and Toughest Mile in Transportation (Sara Hendricks)

5. Bringing Extraordinary Data to Your Everyday Work (Phil Winters moderating)

6. Technology's Growing Impact on TDM and Universities (Phil Winters)

7. Commuter Benefits Jeopardy! 2016 (Phil Winters)

8. Results of the 2016 Employer Benchmarking Survey \& Spotlight Examples (Phil Winters)

Clearinghouse staff is assisting the Association for Commuter Transportation with the development of a formal TDM credentialing program. The contractor hired by ACT expects the first exam to be launched in mid to late 2018 . 


\section{Task 3: Special Projects}

Employer Benchmarking Survey analysis was conducted in partnership with the ACT's Employer Council. The survey received under 100 completed surveys. The report can be found on the Best Workplaces for Commuters' website at https://www.bestworkplaces.org/data/2016-employer-benchmarl<ing-survey 